\begin{tabular}{|c|c|}
\hline \multirow{2}{*}{ MAGNA } & Research Article \\
MEDIKA & Berkala Ilmiah Kedokteran dan Kesehatan \\
\cline { 2 - 2 } & Journal Page: https://jurnal.unimus.ac.id/index.php/APKKM
\end{tabular}

\title{
Relationship between Motivation and Type II Diabetes Mellitus Die- tary Compliance
}

\author{
Rofiq Farhi Nashrullah', Nugroho Ari², Siswanto Agung ${ }^{3}$, Asta Adyani ${ }^{4}$ \\ 1,3)Fakultas Ilmu Kesehatan, Universitas Muhammadyah Surabaya \\ 4)Public Health Department, National University of Malaysia
}

\begin{tabular}{l}
\multicolumn{1}{c}{ Article Info } \\
\hline Article history: \\
Received 02 May 2021 \\
Revised 20 June 2021 \\
Accepted 24 June 2021 \\
Available online 01 August 2021 \\
Keywords: \\
Dietary, Motivation, Diabetes Mellitus, \\
Compliance \\
\hline
\end{tabular}

\section{Correspondence:}

astadyani19@gmail.com

\footnotetext{
How to cite this article:

1. Nashrullah RF, Ari N, Agung S, Adyani A. Relationship between Motivation and Type II Diabetes Mellitus Dietary Compliance. MAGNA MEDIKA Berk Ilm Kedokt dan Kesehat. 2021;8(2):60-70
}

\begin{abstract}
Background: High number of people with DM in the world has increased globally every year. Different Lifestyles since the patient on hospitalized and when the patient carries out from the hospital become a problem in many countries, including Indonesia. The condition during hospitalization will cause saturation for $\mathrm{DM}$ patients. Therefore, motivation to comply with the blood glucose diet by adjusting the diet is essential to DM patients. DM patients must adjust their diet according to the principles of the DM diet suggested by health workers since they can keep their blood sugar under control by adjusting the patient's diet.
\end{abstract}

Objective: To explore the relationship between motivation and dietary compliance with type $2 \mathrm{DM}$ patients in Galis village, Galis Health Center, Pamekasan District

Method: It was observational research with a cross-sectional study conducted on people with DM Type $2(\mathrm{~N}=30,20$ to 70 years old). A 19 items Butler Motivation and ten items Dietary of Behaviour questionary were used. Statistical analysis was done using SPSS (21.00 version).

Results: Most of the type 2 DM sufferers experienced high motivation, and sufferers comply with the type 2 diabetes mellitus diet.

Conclusion: There is a relationship between motivation and adherence to type 2 diabetes mellitus. 


\section{INTRODUCTION}

Diabetes Mellitus (DM) is a group of metabolic diseases that has characteristics in blood glucose levels (hyperglycemia) escalation occurred due to abnormalities in insulin secretion, insulin action, or both ${ }^{1}$. According to Soegondo, DM occurs when the body does not produce enough insulin to maintain normal blood sugar levels or when cells do not respond to insulin appropriately ${ }^{2}$.

Several risk factors influencing the occurrence of DM including unhealthy eating patterns in which they tend to consume excessive carbohydrates and glucose sources continuously; if DM sufferers do not comply with the treatment program recommended by doctors, nutritionists, or other health workers, it will lead to problems that can worsen the condition of the disease. There are still several people who do not comply and understand how to have a good DM diet. Therefore, having a dietary arrangement for DM patients in consuming food and applying it in daily eating habits based on the body's needs is compulsory. For DM patients, adjusting the diet is not easy since the menu consumed is entirely restricted. This condition will cause saturation for DM patients; therefore, motivation to comply with the blood glucose diet by adjusting the diet is essential to be committed by the DM patients. Motivation is pivotal since it triggers an individual to do something to achieve the expected goal $^{3}$. High self-efficacy and knowledge have a positive impact on lifestyle adherence and consequently result in better clinical outcomes ${ }^{24}$. The other Researchers found that participants in the higher-income group tend to consume higher calorie intake than those in the lower- income group. This is one of the sociocultural issues that needed for further exploration ${ }^{25}$.

The number of people with DM continuously increases globally every year, 239.3 million according to data published by the World Health Organization ${ }^{4}$. The number of DM sufferers in Indonesia, according to the International Diabetes Federation (IDF), is estimated to be 5.6 million in 2000, and in 2020 there will be 178 million people over 20 years of Age and assuming a DM prevalence of 4.6\%, 8.2 million DM patients will be obtained ${ }^{2}$. This high number has turned Indonesia into the seventh-highest number of DM sufferers worldwide after China, India, the United States, Brazil, Russia, and Mexico ${ }^{5}$. The number of DM patients in Surabaya in 2000 was 50.000 patients. According to the management of the Indonesian Diabetes Association (PERSADIA) Subagijo Adi, the number of DM sufferers is $6 \%$ or 2.248.605 people from the total population of East Java 37.476 .757 people in East Java, Basuki's 2004 study of DM patients stated that $75 \%$ of DM did not comply with the diet suggested. Based on the results of pre-research on March 24, 2011, in the inpatient room of Baptist Kediri Hospital, based on the interviews conducted with $10 \mathrm{DM}$ patients, it was found that $7(70 \%)$ DM patients who did not comply to diet due to lack of family support, and $3 \mathrm{DM}$ patients $(30 \%)^{7}$. Based on Indonesian Basic Health Research Data in 2018 quoted from the Indonesian Ministry of Health in 2018, East Java is included in the top 5 regions with the most DM sufferers, namely $2.5 \%$ after DKI Jakarta 3.4\%, East Kalimantan 3.1\%, DI Yogyakarta 3\%, and North Sulawesi 2.6\%. Based on the 2019 East Java health profile data, Pamekasan is the number 28 region of all regions in 
East Java which has the most DM sufferers related to low health behavior among other cities. Based on the Galis Health Center data results in October - December 2015, 58 DM sufferers carried out control at Galis Health Center, Galis District, Pamekasan Regency. Based on information obtained from health workers at the Galis Health Center in Pamekasan Regency, the average DM sufferers will comply with the recommendations and suggestions from the health workers when they are hospitalized. However, the irregular lifestyle will return as the patients return home as they carry out the routine and forget about their previous physical condition. Thus, the illness suffered is worse, high blood glucose levels and complications occur. Different Lifestyle: Since the patient is hospitalized and the patient carries out from the hospital becomes a problem in many countries, including Indonesia, the condition will cause saturation for DM patients. Therefore, motivation to comply with the blood glucose diet by adjusting the diet is essential to DM patients.

According to Wade \& Travis, motivation is a process in humans, causing individuals to move towards the goals they have or move away from improper situations ${ }^{8}$. Behavioral attitudes individual health is also influenced by individual self-motivation to act healthily and maintain health. Without motivation in dietary settings, DM patients will experience noncompliance in regulating their daily diet. DM patient compliance in carrying out a diet is one of the essential matters in controlling DM. Patients must adjust their diet according to the principles of the DM diet suggested by health workers since they can keep their blood sugar under control by adjusting the patient's diet'.
Compliance is the indicator to which patients comply with clinical recommendations from doctors who handle them ${ }^{10}$. According to Sacket, compliance is the extent to which the patients' behavior follows the provisions given by a health professional ${ }^{11}$. In practice, compliance is defined as the level of the patient carrying out the treatment and behavior recommended by a doctor or paramedic, as the provisions recommended in DM sufferers. Many DM patients experience failure in treatment, which might be caused by various factors, not complying with the proper diet. Complications from DM that can arise due to non-compliant patients carrying out the therapy program are dietary regulation, exercising, and drug usage. For hospitalized patients, controlling blood sugar levels is carried out every morning, here patients who are regularly treated with a pattern of therapy and the diet will look stable; however, for non-compliance patients to therapy and diet in the morning, the increase of blood sugar levels will occur.

Diet is a habit about the amount and type of food and drinks an individual consumes daily, especially foods regulated to improve individuals' specific needs by including and excluding certain foods. According to Hartono, diet regulation sets the type and amount of food for specific purposes such as maintaining health and nutritional status and helping to cure disease $^{12}$. Every diet includes food, but not all foods are included in the diet category. On a diet, the type and amount of food are determined and controlled to achieve specific goals. A diabetic diet is a diet that is recommended for people with DM; usually, it is restricted in the amount of sugar or easily absorbed carbohydrates. In addition to controlling sugar levels regularly, having a regular diet and exercise is the key to successful diabetes management. 
From the above background, researchers are interested in exploring the relationship between motivation and compliance with type 2

\section{METHODS}

The research used is observational research with a cross-sectional design. Populations in this study were all patients as many as 50 with Type 2 Diabetes Mellitus (DM) around Puskesmas Galis working area in October-December 2015. This study used Non-Probability Sampling with a consecutive sampling ${ }^{13}$. The sample of this study was 30 respondents with type $2 \mathrm{DM}$ patients. The independent variable is the motivation of type 2 DM patients, and the dependent variable in this research is the dietary compliance of type $2 \mathrm{DM}$ patients. This research was conducted in Galis Village, the working area around Puskesmas Galis, Pamekaran Regency, for two weeks.

In this study, the instruments used are:

1). Motivation Questionnaire

A 19 items motivation questionnaire sheets was used Scoring is given by: Strongly agree = 4 Agree $=3$ Disagree $=2$ Strongly disagree $=$ 1. Classification: Hight $=76-100 \%$ Medium $=$ 56- 75\%. The Questionnaire Developed from Buttler Motivation Questionnaire 2010, The Questionnaire was adopted from Buttler 2010, translated into Indonesian, adjusted to the conditions of the target population, and performed validation and reliability. Test

2). Dietary compliance for DM type 2 and observation

A 10 Items Question about the behavior of DM Dietary was developed from Notoatmodjo 2010. The Questionnaire on dietary diabetes on DM patients in Galis Village, Galis Health Center Pamekasan Regency.

compliance behavior in each question was given yes and no answer choices. Scoring for Yes and No answer choice was given Yes = 1, No $=0$. The classification is based on the number of questions answered and the number of questions multiplied. then classified into $2 \mathrm{op}-$ tions Categories: there are obedient $=60$ $100 \%$ disobedient $\leq 50 \%$ (Notoadmojo, 2010).

The data analysis in this research used Fisher's exact test because the data scale is ordinal, and the cell has an expected value below $20 \%$. This study is intended to find a correlation between motivation and dietary compliance.

\section{RESULTS}

\section{Characteristics Respondents}

Most respondents aged 30-48 are 21 (70.0\%), and gender reveals that most respondents are 16 women $(53.3 \%)$. Education reveals that most respondents $(60.0 \%)$ received their education in Junior and Senior High School, while seven attended college (23.3\%). Occupation reveals that 13 respondents work as private employers $(43.3 \%)$ as in table 1.

\section{Dietary Compliance of Patients with Type 2 Diabetes Mellitus}

The distribution of motivation of patients with type 2 Diabetes Mellitus in the working area of Puskesmas Galis Pamekasan Regency in Galis Village, as in table 2, shows high motivation with several 17 respondents (56.7\%) and those whose moderate motivation were 13 respondents $(43.3 \%)$. At the same time, there were no patients whose motivation was low $(0 \%)$. 
Table 1 Distribution of Respondent databased on Demographic (Age, Gender, Education, and Occupation) of Patients with Type 2 Diabetes Mellitus

\begin{tabular}{llcr}
\hline \multicolumn{1}{c}{ Variable } & \multicolumn{1}{c}{ Description } & Frequency & Percent \\
\hline \multirow{4}{*}{ Age } & $30-36$ y.o & 9 & $30,0 \%$ \\
(year's old, y.o) & $37-42$ y.o & 9 & $30,0 \%$ \\
& $43-48$ y.o & 3 & $10,0 \%$ \\
\multirow{3}{*}{ Gender } & $49-54$ y.o & 5 & $16,7 \%$ \\
& $55-60$ y.o & 4 & $13,3 \%$ \\
& Male & 14 & $46,7 \%$ \\
\multirow{3}{*}{ Education } & Female & 16 & $53,3 \%$ \\
& None & 3 & $10,0 \%$ \\
& Elementary school & 2 & $6,7 \%$ \\
& Junior high school & 9 & $30,0 \%$ \\
& Senior high school & 9 & $30,0 \%$ \\
& College (Diploma 1, Diploma 2, Diploma & 7 & $23,3 \%$ \\
& 3, Bachelor, Master) & 13 & $43,3 \%$ \\
& Private employee & 1 & $3,3 \%$ \\
& Entrepreneur & 1 & $3,3 \%$ \\
& Civil servant & 11 & $36,7 \%$ \\
& Housewife & 4 & $13,3 \%$ \\
\hline
\end{tabular}

Based on table 2, the distribution of dietary compliance data of patients with type 2 Diabetes Mellitus in the working area of Puskesmas Galis, Galis Village Pamkasan Regency shows that 17 respondents with DM were compliant $(56.7 \%)$ and 13 respondents with DM were non-compliant (43.3\%).

Table 2. Distribution of Respondents' Data Based on Motivation and Dietary Compliance of Patients with Type 2 Diabetes Mellitus

\begin{tabular}{lcc}
\hline Motivation & Number & Percentage \% \\
\hline High & 17 & 56.7 \\
Moderate & 13 & 43.3 \\
\hline Total & 30 & 100 \\
\hline Dietary Compliance & Number & Percentage (\%) \\
\hline Compliant & 17 & 56,7 \\
Non- compliant & 13 & 43,3 \\
\hline Total: & 30 & 100 \\
\hline
\end{tabular}




\section{Association between Motivation and Dietary Compliance with Type 2 Diabetes Mellitus}

Table 3. Cross Tabulation between Relationship between Motivation and Dietary Compliance with Type 2 Diabetes Mellitus

\begin{tabular}{lcccccc}
\hline & \multicolumn{4}{c}{ Dietary Compliance } & \multirow{2}{*}{ Total } \\
\cline { 2 - 5 } Motivation & \multicolumn{2}{c}{ Compliant } & Non-compliant & & \\
\cline { 2 - 5 } & $\mathrm{n}$ & $\%$ & $\mathrm{n}$ & $\%$ & $\mathrm{~N}$ & $\%$ \\
\hline High & 15 & 50,0 & 2 & 6,7 & 17 & 56,7 \\
Moderate & 2 & 6,7 & 11 & 36,7 & 13 & 43,4 \\
Total & 17 & 56,7 & 13 & 43,4 & 30 & 100 \\
\hline The test result of Fisher's exact test $\mathrm{p}$-value $<0.00$ Odds Ratio: 41,25 \\
\hline
\end{tabular}

Based on the results of the Fisher's exact test using SPSS 21 at table 3, the significance p-value is 0.00 , and the OR is 41,25 because the p-value $0.00<0.05$ then $\mathrm{H}_{0}$ is rejected so that there is a relationship between motivation and dietary compliance of type 2 Diabetes Mellitus. The OR 41,25 in the Fisher's exact test adjusted to the correlation criteria interpretation according to Sugiyono (2008), it is obtained a strong correlation result.

\section{DISCUSSION}

\section{Identification of Motivations of Patients with Type 2 Diabetes Mellitus}

Motivation is individual's behavior or attitude to satisfy their needs, and it is because basically human has needs and desires. Motivation is also a person's thoughts in viewing the task or goal $^{14}$. Motivation is a concept that explains behavior; an innate response is referred to behavior ${ }^{15}$. According to Robbins, motivation is a process to explain individuals' intensity, direction, and persistence to achieve their goals ${ }^{16}$. According to Swanburg \& Swanburd, motivation within a person will manifest behavior directed to achieve satisfaction ${ }^{15}$. According to
Da Silva, High motivation can increase patients' compliance with type $2 \mathrm{DM}$ on their self-care ${ }^{17}$

According to Hodges, motivation is psychological that both directly drives and controls a person $^{18}$. The meaning contained in it is encouragement and motive, in which the motive plays a pivotal role since it contains behavior, meaning that in the context of the dietary transformation of DM patients, recovering and reducing disability due to suffering from DM is based on the patients' desire.

Factors influencing motivation are divided into 2 , intrinsic factors and extrinsic factors. Intrinsic factors are physical and mental processes, insight or education, needs or necessities, and types of gender ${ }^{19}$. In contrast, the extrinsic factors are environment, facilities, conditions, socio-economic or work situations. Based on the research results, it was found that most educational levels are Junior High School and Senior High School with the same number of respondents, nine respondents $(20.9 \%)$ respectively. Education is an activity deliberately carried out to obtain results in the form of a person's knowledge, skills, and attitudes; thus, individuals who receive an education will quickly 
motivate themselves. The same as those with type $2 \mathrm{DM}$ patients who received high-level education will have high motivation to recover from type $2 \mathrm{DM}$. This condition occurred because education is an intrinsic factor affecting motivation. Motivational interview is a crucial strategy, as it is designed to 'reinforce personal motivation and commitment to a specific goal, by eliciting and explore the person's reasons for change. ${ }^{28}$

The female sex tends to be more active in activity compared to men. This is due to women tend to be in a group compared to men. It is shown in this research that the majority were 16 women $(37.2 \%)$ involved. Occupation is also an extrinsic factor that might affect motivation. The busyness of working becoming their routine sometimes turns them into saturation which affects their level of motivation. In this study, 11 respondents work as housewives with a percentage $(25.6 \%)$, and 13 respondents work as private employees with a percentage $(30,2 \%)$.

Based on the results of the research show that characteristic demographic of Age are majority respondents \% are 49-54 years old, gender shows that the majority of the respondent's was 16 women (37.2\%), Education Items shows that the majority of respondents' education in Junior High School were nine respondents $(20.9 \%)$ and based on occupation shows that 13 respondents work as Private employees $(30.2 \%)$. According to theories, it can be assumed that motivation is influenced by various things, including education, gender, occupation, and environment. The surroundings can affect the behavior or attitude and steps taken in the mindset to determine one action, in this case, on people with type $2 \mathrm{DM}$. If the patients want to recover or have balanced blood sugar levels, they have high motivation. Motivation has a prominent role since it can lead an individual to achieve the expected goal. Motivation for people with Diabetes Mellitus is a form of responsibility for the disease they suffered.

\section{Identification of Diabetes Mellitus Type 2 Dietary Compliance}

The data obtained from the observation of the booklet found that respondents mostly had regular meal schedules but did not pay attention to the number of calories consumed and the types of sugar that must be avoided.

Compliance (Adherence) is a behavior or attitude in complying or adhering to a recommendation of daily habits and can be assessed by a research score. Compliance is influenced by the level of education, in which education is the primary basis for successful prevention of treatment ${ }^{20}$. Some previous studies found a direct relationship between self-efficacy and lifestyle management; self-efficacy increases adherence, consequently reducing the barrier to changes. The participants specified the following factors were the obstacles in adopting lifestyle change recommendations, which are food accessibility, food habits, stress, lack of time, lack support, and low motivation level ${ }^{26,27}$

According to Carpenito argues that the factors influencing the level of compliance are anything that contributes positive effect so that the patient is no longer able to remain compliant until they become less compliant and noncompliant. There are factors affecting compliance: 1. Management of instructions, for instance, no one will comply with instructions if they misunderstand the instructions given to them $^{21}$. 2. The level of education, for instance, 
the level of education, can elevate compliance as long as that education is an active education obtained independently. As the results of this research, most education levels are Junior High School and Senior High School, with several nine respondents $(20.9 \%)$ respectively ${ }^{21}$. 3. Illness and Medication, for instance, lower compliance behavior for chronic disease (due to no immediate harmful effects or obvious risks encountered $)^{21} .4$. Beliefs, attitudes and personalities, personalities between compliance people and those who fail, non-compliant people suffer depression, anxiety, very concerned about their health, have a more social life, and focus on themselves ${ }^{21}$. 5. Family support can be an influential factor in determining individuals' health beliefs and values in determining the treatment program they will receive $e^{21}$.

6. Economic level, the economic level is the financial capability to fulfill all the necessities of life through working or not, but usually, other financial sources are reliable to fund all the treatment and care programs expanse. Therefore, people from the lower-middle economic level are non-compliant ${ }^{21}$. 7. Social support as an example social support in the form of emotional support from members, friends, time, and money are pivotal factors of compliance. For instance, if there is no transportation and costs can reduce anxiety caused by the disease $^{21}$. 8. Habits can influence healthy behavior. Therefore, it is necessary to develop a strategy that is to alter behavior and maintain this transformation ${ }^{21}$. 9. Nursing professional support (health), health professional support is another factor influencing patients' compliance ${ }^{21}$.

Based on the results of the research and existing theories, it can be assumed that the factors that can affect dietary compliance are management of instructions, Educational level, illness and medication, Beliefs, personality and family support, economic level, social support, healthy behavior, professional support and nursing (health). Diabetes Mellitus diet is a way for people with DM to feel comfortable, prevent more severe complications and improve eating habits to gain better metabolic control by lowering blood sugar levels approaching normal through balancing food intake, insulin/glucose-lowering drugs, oral and physical activity, reducing glucose in urine to negative and reducing polydipsia (frequent urination), providing enough energy to maintain or reach the standard weight and establish the main pillars in DM therapy. Thus, regular activity can be carried out by people with DM

The ability of DM patients or sufferers to control their lives can affect the level of compliance; a health-oriented individual tends to adopt all habits that can improve health and accept all kinds of things that will restore their health. Therefore, those who think DM is lifethreatening and dangerous for their life will consider transforming their eating pattern and lifestyle; hence dietary compliance tends to be high.

\section{The Relationship Between Motivation and Dietary Compliance of Type 2 Diabetes Mellitus}

Motivation is individual behavior to satisfy their needs due to essential humans have needs and desires. Motivation is also a person's thoughts in viewing a task or goal ${ }^{14}$-motivation as a concept that explains behavior and innate responses referred to within behavior ${ }^{15}$. According to Robbins, compliance is the patient's behavior undergoing medication, following a diet, or following others' lifestyle transformation following medical and health recommendations ${ }^{16}$. Compliance is the main 
thing because following the advice of a medical expert is one way to cure patients ${ }^{22}$.

In line with the research, there is a relationship between motivation and dietary compliance of the type $2 \mathrm{DM}$; in this study, it was explained that most patients had the high motivation and were compliant with the type $2 \mathrm{DM} \operatorname{diet}^{23}$. Besides, a study conducted by Tombokan found a significant relationship between patient motivation and compliance with type $2 \mathrm{DM}$ patients to commit treatment at the family doctor $\operatorname{clinic}^{18}$. The motivation of people with diabetes mellitus in carrying out treatment can low can also be high. This can be caused by many factors that can affect a person's motivations for doing treatment well-one of the factors that can affect people's motivation with diabetes. Mellitus is a need. Thing This is under the opinion of Maslow (1994) that in everyone there are five needs which include: needs physical (physiological needs); included in Inside is the need for food drinking, need for security needs); including care or protection from physical threats and emotional. The need to live treatment for diabetics Mellitus is a physical need that must be fulfilled, so to fulfill the needs of people with diabetes mellitus, people with diabetes mellitus need to do the treatment well. In addition, support from the family to go very well is needed to increase motivation in undergoing treatment. ${ }^{18}$

Based on existing research in the work area of Puskesmas Galis Pamekasan and existing theories, it can be assumed that those who suffer from type $2 \mathrm{DM}$ and has high motivation tend to comply with the DM diet. Whereas those who intend to lower their blood sugar levels become balance, they have high motivation to lower their blood sugar levels. Therefore, the only way is through committing a Diabetes Mellitus diet. This study has proven that most high motivation type 2 DM diets comply(adhere) to the diabetes diet.

\section{CONCLUSION}

Most people with Type 2 DM experience high motivation, and most people with type $2 \mathrm{DM}$ adhere to a type $2 \mathrm{DM}$ diet, and there is a relationship between motivation compliance with type $2 \mathrm{DM}$ diet.

\section{REFERENCES}

1. Smeltzer SC, Bare BG, Hinkle JL, Cheever KH, Townsend MC, Gould B. Brunner and Suddarth's textbook of medical surgical nursing 10th edition. Philadelphia: Lippincott Williams \& Wilkins; 2008.

2. Soewondo P, Soegondo S, Suastika K, Pranoto A, Soeatmadji DW, Tjokroprawiro A. The DiabCare Asia 2008 study â Outcomes on control and complications of type 2 diabetic patients in Indonesia. Med J Indones. 2010;19(4):235-44.

3. Susanti CE, Tedjasuksmana B. Effect Of Knowledge On Nutrition Diet Behavior With Attitude To Mediation Functional Foods For Diabetes Mellitus Patients In Surabaya. In: Conference In Business, Accounting, And Management (CBAM). 2021. p. 151-64.

4. Tao Z, Shi A, Zhao J. Epidemiological perspectives of diabetes. Cell Biochem Biophys. 2015;73(1):181-5.

5. Roifah I. Analisis hubungan lama menderita diabetes mellitus dengan kualitas hidup penderita diabetes mellitus. J Ilmu Kesehat. 2017;4(2):7-13.

6. Amaliah AN, Febriza AMI. The Relations Between Diabetes Mellitus Type 2 on The Incidence Cataract in Balai Kesehatan Mata 
Makassar in 2016. MAGNA MEDICA Berk

Ilm Kedokt dan Kesehat. 2019;6(1):99-106.

7. Susanti ML, Sulistyarini T. Dukungan keluarga meningkatkan kepatuhan diet pasien diabetes mellitus di ruang rawat inap RS. Baptis Kediri. J Stikes. 2013;6(1):1-10.

8. Crust L. A review and conceptual reexamination of mental toughness: Implications for future researchers. Pers Individ Dif. 2008;45(7):576-83.

9. Azis A, Aminah S. Pengetahuan, Motivasi dan Kepatuhan Diet Pasien DM Tipe II di Wilayah Kerja Puskesmas Kaliwungu Kendal. J Smart Keperawatan. 2018;5(1):72-9.

10. Goldberg DM. The Impact of Physician Communication on Mental Health Service Utilization. Indiana University; 2019.

11. Niven N. Psikologi kesehatan: pengantar untuk perawat dan profesional kesehatan lain. In EGC; 2000.

12. Susanti A, Ennawati D. Dietary Habit and Physical Activity in Cases of Hypertension in Kedung Cowek Surabaya. In: The 3 rd International Symposium of Public Health (The 3 rd ISoPH) "Challenging Public Health Roles Towards Global Health Issues.” p. 59.

13. Alimul Hidayat AA. Metode Penelitian Kesehatan Paradigma Kuantitatif. Vol. 19, Jakarta: Heath Books. 2010.

14. Marquis BL, Hutton CJ. Leadership roles and management functions in nursing: theory and application 5th edition. Manila, Philippines: Lippincott Williams \& Wilkins. 2006.

15. Swansburg RC. of motivation and process (endogenous) theories. Introd to Manag Leadersh Nurse Manag. 2002;412.

16. Ariani DW. Personality and learning motivation. Eur J Bus Manag. 2013;5(10).

17. Da Silva J. Motivation for self-care in older women with heart disease and diabetes: A balancing act. University of California, San Francisco; 2003.

18. Tombokan V. Faktor-faktor yang berhubungan dengan kepatuhan berobat pasien diabetes melitus pada praktek dokter keluarga di Kota Tomohon. JIKMU. 2015;5(3).

19. Notoatmodjo S. Pendidikan dan Perilaku Kesehatan. Metodologi Penelitian Kesehatan. Jakarta: PT Rineka Cipta; 2005.

20. Rahmawati SD, Wahyuningsih AS, Yalestyarini EA. Diet Compliance Analysis Towards Blood Sugar Levels For Diabetes Mellitus Patients. J Nurs Pract. 2018;2(1):73-9.

21. McKinney AA, Deeny P. Leaving the intensive care unit: a phenomenological study of the patients' experience. Intensive Crit Care Nurs. 2002;18(6):320-31.

22. Horne R, Weinman J, Barber N, Elliott R, Morgan M, Cribb A, et al. Concordance, adherence and compliance in medicine taking. London: NCCSDO. 2005;2005:40-6.

23. Andhika DA, Ahmad Farudin SKM. Hubungan Motivasi Diri Dan Dukungan Keluarga Dengan Kepatuhan Diet Pada Pasien Diabetes Mellitus. Universitas Muhammadiyah Surakarta; 2020.

24. Mishali, M., Omer, H. and Heymann, A.D. (2011), "The importance of measuring selfefficacy in patients with diabetes," Family Practice, Vol. 28 No. 1, pp. 82-87, DOI: 10.1093/camera/cmq086

25. Mahdavi, R., et al. (2018), "Contribution of barriers to dietary intake in female patients with type 2 diabetes", Nutrition and Food Science, Vol. 48 No. 3, pp. 510-519, DOI: 10.1108/NFS-04-2017-0080

26. Amer, F.A.M., et al. (2018), "Influence of selfefficacy management on adherence to self-care activities and treatment outcome among diabetes mellitus type 2 Sudanese patients", Pharmacy Practice, Vol. 16 No. 4, pp. 1-7, 
27. Adu, MD et al. (2019), "Enablers and barriers to effective diabetes self-management: a multinational an investigation," PLoS One, Vol. 14 No. 6, pp. 1-22,
28. Ra1'ssa A.P et al. (2020) Strategies designed to increase the motivation for and adherence to dietary recommendations in patients with chronic kidney disease Nephrol Dial Transplant (2020) 1- DOI: 10.1093/ndt/gfaa177 